\title{
The Trend of College English Teaching Reform Based on Employment Orientation
}

\author{
Yuanyuan Yang \\ School of Foreign Studies, Xi'an University, 710065
}

Keywords: Employment orientation; College English teaching; Reform trend

\begin{abstract}
With the rapid development of China's economy and the continuous expansion of institutions of higher learning, college graduates face both the opportunities and the challenges. In view of this, colleges and universities should start from the subject education and increase the connection between English teaching and employment, so as to fundamentally solve the direct split relationship between English teaching and employment. This paper mainly studies the existing problems of English teaching in colleges and universities, and analyzes the reform trend of English teaching in colleges and universities, hoping to provide some references for improving the quality of English teaching and promoting students' smooth employment.

At present, China's economy has developed steadily, and local colleges and universities have been expanding their enrollment. College graduates are faced with different opportunities and challenges in the new period. In view of this, institutions of higher learning should start from the subject education and increase the connection between English teaching and employment, thus to help be ready to graduate when they entry the colleges and universities.
\end{abstract}

\section{The Main Problems of English Teaching in Chinese Colleges and Universities at Present Stage}

The Problem of Teacher Resource. Currently, full-time English teachers in colleges and universities commonly use the traditional way to carry out teaching, that is, the passive teaching mode of teachers teaching and students receiving. Although the teaching model can complete the teaching tasks of colleges and universities, it is far away with the current stage of social needs. The teaching effect of the mode of simple examination and teaching is yet unsatisfactory. As the passive teaching does not form effective closed-loop feedback in the process of learning, it is difficult for teachers to understand the learning situation and needs of students, and students cannot get better learning incentives in the learning process, which then leads to the playing difficulty of subjective initiative of learning. In addition, a considerable number of teachers do not have too much job-hunting experiences before serving as their own work, and even some teachers have never had a job interview. Therefore, the links between curriculum and employment in teaching process are out of question for these teachers.

\section{The Problem of Course Setup}

At present, the course of English teaching in colleges and universities generally presents the characteristics of emphasizing theory and neglecting practice. Compared with the rapid development of modern society, the setup of course content is slightly disjointed without timely update rate and high reduction degree of authentic language setting. English teaching contents often give students a boring learning atmosphere, which is difficult to improve the enthusiasm of students to learn. In addition, most of the institutions of higher learning have ranked English teaching as the basic public curriculum. On one hand, it shows the importance of English teaching in colleges and universities. On the other hand, the English teaching is separated artificially with the majors the students learnt, which leads to the relative isolation of English teaching in colleges and universities. The direct consequence of this phenomenon is the slightest impression on the students that the study of English is more of a pressure on test scores than a useful skill linked with job selection after graduation. In the design of English teaching courses, some institutions also take into account the problem of combining with the corresponding major and set up a different degree of professional English courses, but these courses generally have the problems of weak pertinence, the course with old content, and far away from actual application, which cannot be satisfactory. 


\section{The Problem of Course Assessment}

At present, the assessment of English courses in colleges and universities is generally used in the form of closed-book written examination to test students in terms of English listening, speaking, reading and writing. This form of assessment focuses on the analysis of grammatical semantics, and neglects the language as a basic tool of communication among people, of which the core function is the communication effect of information transfer in the actual communication. The direct impact of this assessment is too much emphasis on the students' memory of the teaching knowledge, while ignoring the knowledge of the application and understanding for students. Assessment items are often focused too much on reading and writing, while it is not enough for listening and oral examinations, which is likely to cause dumb English.

\section{The Differential Analysis between English Teaching and Employment Orientation in Colleges and Universities}

\section{Aspect of Students}

The current English teaching model of higher education institutions has led to the fact that most non-English majors' motivation and ideas for English learning have always stayed in terms of test scores, credit requirements or scholarships. Students are not enthusiastic about learning English, and subjective initiative is not strong. Even if the students with better learning initiative have the problems of less abundant of knowledge reserves, large deviation of learning content and the actual needs, and disjointed with the reality. A considerable part of the students, on one hand, will not actively consider obtaining the corresponding English qualification certificate except the CET 4 \& 6 which will affect the graduation; on the other hand, they are not familiar with the English needs of their majors, therefore, English ability cannot be shown as a core skill to the employer in the employment and career choice. On the contrary, it has become a shortcoming for employment, leading to dissatisfactory employment and career choice. These defects can be successfully avoided through the guidance and help of college English teaching.

\section{Aspect of Teachers}

First of all, from the age structure, it is not ideal for the age structure of teachers in a considerable part of the institutions of higher learning in English teaching. A significant proportion of English teachers are younger, with the advantages of the knowledge system being more modern and advancing attitude with the times more open, but the resulting defects are the relative lack of teaching experience and the link between English teaching and employment in colleges and universities is not close enough. In the overall number of English teachers, the numbers of key teachers and academic leaders are not enough. In addition, from the teaching measures and methods, the condition of passive teaching is relatively common traditionally used by college English teaching with the relatively simple teaching methods, which is not conducive to students to improve the enthusiasm in English learning. It is low for the use of English in the actual scene of the reduction, resulting in the great reduction of English teaching effect.

\section{Aspect of Teaching Materials}

The teaching materials commonly used in English teaching in colleges and universities are relatively fixed, with the long renewal cycle and the slow speed, and treating English as the general basic course. The advantage of this approach is that the versatility of the majors is strong, which has a certain universal significance. However, the problem is that the distance between college English teaching materials and practical application is getting bigger and bigger, and the renewal period of teaching materials determines the gap between teaching effect and practical application. In addition, the versatility of English textbooks also means that the distinctions of English practical application in different majors are relatively lower and the connection between English teaching and professional knowledge is not close enough, of which the scope of professional English is fragmented.

\section{Aspect of Course Setup}

College English teaching is generally arranged in the first two years of university admission as a basic teaching course. However, from the perspective of language learning, English learning is a 
lifelong learning process. From the purpose of communication, the use of English is a process of long-term repeated stimulation. These require college English teaching to guide students in their daily study and life not only to learn English as a learning habit at any time, but also to treat English as a communication skill and mean to use and practice repeatedly. Only basic learning in the first two years of university admission is difficult to guide students to adhere to the effect of learning English. Although most of the curriculums in colleges and universities set up a course of professional English in junior or senior, on one hand, as limited by the nature of the course, many professional English is characterized as a major elective course. On the other hand, as the class hour of course setup is limited, and many professional English courses are not closely related to the actual professional content, it leads to poor actual teaching effect of professional English courses, which has few effects on guiding the enthusiasm for students to continue to learn English.

\section{Aspect of Teaching Environment}

In recent years, the scale of infrastructure in colleges and universities is expanding, the hard power of colleges and universities is increasing day by day, and multimedia teaching places are constantly building up. For college English teaching, the improvement of hardware facilities, of course, is a good thing, but it cannot solve all the problems. At present, the environmental problems of college English teaching cannot be resolved by simply stacking hardware facilities, what is more important is the language learning environment. College English teaching should strive to create a more realistic English learning environment for students, rather than just leave the English learning to the students of consciousness. College English teaching should strive to restore the nature of language learning, rather than rely on the students to learn English in mechanical repetition. College English teaching should focus on the effectiveness of language communication, rather than allow students to focus more attention only on the test scores. Only making students return the focus of English learning to the most essential communication application of the language can college English teaching better solve the connection between the practicality of English teaching and student employment orientation.

\section{Aspect of Assessment}

Generally, the method of college English teaching assessment is more single, of which the examination mode of closed-book answer is the dominant part and the proportion of objective problems is relatively large. This model is generally applicable to examine the candidates for the provisions of the learning content and core focus on the degree of memory and understanding. However, for English learning, especially to the English learning stage of the institutions of higher learning, the need for simple memory content is relatively small without the need the mechanical memory syntax and semantic structure any more. The current assessment methods do not apply to the requirements of English application level in colleges and universities, but also contrary to the concept of quality education in modern education. The current teaching assessment investigates greater in students' reading and writing, but neglects the students' ability of the exercise in listening and speaking. This assessment mode is not conducive to the exercise of exchange of language functions, which is easy to fall into the dumb English circle. The direct impact of this assessment is the subtle influence of students the idea of achievement theory, and is not conducive for students to improve enthusiasm in English learning, nor to guide students the habits of using English. Correspondingly, in the process of students' employment choice, they will not actively think of or highlight the application of English ability, and automatically there is no expression of the employment-oriented function.

\section{The Trend of College English Teaching Reform based on Employment Orientation}

\section{Employment-oriented and Clear Teaching Objectives}

For college English teaching, in order to reflect the discipline for the employment orientation, we must attach importance to the English language itself, that is, language communication and utility. We should pay attention to the use and communication of English itself in daily teaching activities, guide students to take the initiative to use English, strengthen language habits, deepen the language scene, and comprehensively enhance the students' language ability. We should guide students to not 
only read and write, but also to understand and speak in English usage, that is, really treating English as a language habit and communication tool to use, thus to show English as an outstanding skill to employers in employment and career choice so as to increase self- competitiveness.

\section{Building Teachers with High Quality}

The establishment of English teachers in colleges and universities is not a task that can be done overnight. For the teacher's structure, the young team is conducive to accept new things and update faster in the teaching concept. The teaching experience in old team is more abundant. Therefore, we have to establish the teaching staff, on the one hand to keep up with the trend of the times without being disjointed; on the other hand, we also need a considerable number of key teachers and academic leaders to stabilize the team so as to give students a better teaching experience.

\section{Establishing Employment-Oriented Course System}

The use of English is a long process of repeated stimulation. This requires that while setting up college English teaching courses, we should pay attention to guide students in their daily study and life not only to learn English as a learning habit at any time, but also to treat English as a communication skill and mean to use and practice repeatedly. According to the character of different professionals, teachers should teach students in accordance of their aptitude. Professional English course setting should be closely related to actual professional content so that students can learn to apply their English knowledge in the process of employment and career choice.

\section{Creating a Good English Teaching Environment}

To create a positive English learning environment, on one hand, it needs to increase the intensity of hardware facilities; on the other hand, teachers should strive to outline a better language learning environment for students. College English teaching should strive to create students more real English learning environment through the modern technology platform and better restore language learning scenes to transfer students' attention from test scores to the utility of verbal communication. Only making students return the focus of English learning to the most essential communication application of the language can college English teaching better solve the connection between the practicality of English teaching and student employment orientation.

\section{Active Application of a Wide Range of Assessment Methods}

Teaching assessment should be more diversified, not only to examine the ability of students to read and write, but also to have enough attation to students' listening and speaking ability. The examination should be conducive to the exercise of language communication functions, subtly remove the idea of achievement theory of students, and gradually guide students to learn the actual use of English knowledge.

\section{Conclusion}

To sum up, the use of English is a long-term repeated stimulation of the process. For college English teaching, in order to reflect the discipline for the employment orientation, we must attach importance to the English language itself, that is, language communication and utility. Only paying attention to the use and communication of English itself in our daily teaching activities, guiding students to use English actively, strengthening language habit, deepening the language scene, and improving students' language ability comprehensively can we make students to learn the actual use of English knowledge in the process of employment and career choice

\section{Reference}

[1] M.Z. Luo, S.S. Huang, J. Duan: Reflections on curriculum setting and teaching content reform in colleges and universities from the perspective of employment orientation - Based on the questionnaire survey and analysis of students majoring in economics and management. Higher Agricultural Education, Vol. 08 (2013), p. 66. (In Chinese)

[2] S. Wei and Y.J. Sun: A study on the reform of public English teaching in higher vocational education based on "service-aiming and employment-orientation" - A case study of Xingxin Vocational and Technical College of Xinjiang Production and Construction Corps. 
Contemporary Educational Practice and Teaching Research, Vol. 10 (2016). (In Chinese)

[3] H.C. Sun and J. Wu: A study on the countermeasures of English teaching in art-oriented colleges and universities - Taking Hebei Media College as an example. Intelligence, Vol. 09 (2015), p. 150. (In Chinese)

[4] J. Li: Teaching mode of English for ESP in higher vocational colleges - A case study of local economy and employment-oriented reform of public English Teaching in higher vocational colleges. Journal of Jilin Province Education College, Vol. 09 (2012), p. 101. (In Chinese)

[5] Z. Yang: An analysis of the reform of English teaching in higher vocational education with employment as the guidance - A case study of tourism management specialty in Jiangsu Finance and Economics Vocational and Technical College. Vocational Education Newsletter, Vol. 15 (2014), p. 32. (In Chinese)

[6] Y.X. Zhao: Employment-oriented English Teaching reform in higher vocational education - A practical study on the organic integration of industry English and basic English. Journal of Luohe Vocational and Technical College, Vol. 02 (2014), p. 162. (In Chinese)

[7] R.H. Dang and X.Y. Wang: Research on employment-oriented reform of English teaching in colleges and universities - Research on organic integration strategy of tourism English teaching and basic English teaching. Journal of Shandong Institute of Commerce and Technology, Vol. 01 (2013), p. 76. (In Chinese)

[8] Y.C. Yang: The trend of college English teaching reform based on employment orientation. Chinese Adult Education, Vol. 03 (2013), p. 180. (In Chinese)

[9] Y. Cai: Research on employment-oriented college English teaching reform. Education and Teaching Forum, Vol. 11 (2016), p. 125. (In Chinese)

[10] S.Y. Li: The trend of college English teaching reform based on employment orientation. Education Modernization, Vol. 10 (2016), p. 37. (In Chinese)

[11] S.W. Shi and Y.C. Sun: Research on the reform model of college English teaching based on employment orientation. Science and Education, Vol. 07 (2016), p. 166. (In Chinese)

[12]J.B. Ma: A study on the development tendency of college English teaching based on employment. China Market, Vol. 27 (2016), p. 180. (In Chinese) 